\title{
The Perception Reflection Result of the Internship Program 1 Implementation and the Relationship with the Students Commitments in Equipping Themselves to Be A Teacher
}

\author{
Yasaratodo $\mathrm{Wau}^{1 *}$, Anifah ${ }^{1}$, Vidya Dwi Amalia Zati ${ }^{1}$, Fauzi Kurniawan ${ }^{1}$ and Mirza Irawan ${ }^{1}$ \\ \{*yasaratodo@gmail.com $\}$ \\ ${ }^{1}$ Universitas Negeri Medan, Indonesia
}

\begin{abstract}
This study examines the problem (1) how is the perception about the reflection of the Internship program 1 in Non-Formal Education Study Program, (2) how is the students commitment equip themselves to be a teacher in Non-Formal Education FIP Unimed, (3) whether there is a correlation between the results of reflection in the implementation of the Internship program 1 and the increaseof students commitment in equipping themselves as a candidate of teacher in Non-Formal Education FIP Unimed. This study was conducted in Non-Formal Education study program with the entire student of academic year 2016/2017 as population which amount 79 people, all of them have done Internship program in 10 (ten) locations (PKBM) and the research sample is determined by total sampling technique. Data of this research were collected by using questionnaire instrument with Likert Scale pattern. The results of this research will be processed by using correlational descriptive technique. By performing normality and homogeneity test variables, test requirements analysis and test the hypothesis by using $t$ test. The research result shows that (1) the perception about the implementation result of Internship program 1in Non-Formal Education study program is quite enough with an average score of 3.89, (2) Students' commitment to equip themselves to be a teacher in Non-Formal Education FIP Unimed is high with an average score of 4.19.Based on the calculation of correlation analysis between variables, obtained rxy price. of 0.496 which is significant at the level of $95 \%$, so it is concluded that there is a correlation between the perception about reflection result to the implementation of Internship program I, it has a positive relationship with the increase of students commitment in equipping themselves as a candidate of teacher in Non-Formal Education FIP Unimed which significant at 95 percent. The contribution is 24.6 percent. The findings of this study are enough to give sign that Internship program I has the benefit to the establishment of the right perception of self-educator candidates or educational personnel should have a high commitment in equipping themselves to be the professional teachers based on their field of science in college.
\end{abstract}

Keywords: Perception, reflection, internship program, commitment

\section{Introduction}

Non-Formal Education Students is expected to have a commitment or determination or a promise to do all the activities that have been determined by study program. Lecture activities that must be undertaken by students has been designed in such a way by educational 
institutions ranging from the central level (University), the faculty level, the study program levelto the lecturers level who developed courses in each course.One of the compulsory subjects that the previous years were held in the sixth semester, as an opportunity for students to practice theories learned in college in schools or educational units, such as studio, courses, etc., that is Internship program.

The main tasks of the students in the Internship program include (1) Internship 1, that is direct observation of school culture, teacher competence, students, PBM and the last is the reflection of observation results (2) Internship 2, the Stages of studying the practical aspects of school curriculum and its application in the classroom associated with lectures in Unimed, the main tasks of the students include studying curriculum and learning tools, SBM, Evaluation System, designing lesson plans, teaching materials, media and Evaluation tools, (3) Internship 3 , the stage of making lesson plans and the implementation based on the relevance to lectures inUnimed, student's duties include becoming a teacher assistant, teaching, doing the task to accompany the students and the extra-curricular activities.

The policy to determine the three stages of Internship is based on the idea that the competence and spirit of the teachers is not only formed by the experiences and education, but also required a long process, so it needs early exposure, that is giving the experiences as early as possible to the candidate of teachers with the Internships at school (institution / educational unit) in stages.The Internship 1 program has been attended by the students, especially in NonFormal Education study program FIP Unimedas amount 79 people in 10 (ten) locations (PKBM Generasi Muda, PKMBM Walidayna, PKBM Hanuba, PKBM Laskar Pelangi, PKBM Panca Sakti, PKBM Al Manar, PKBM Merah Putih, PKBM Agape, PKBM Sampe Maju and PKBM Karya Muda).

The stages of the implementation activities have been done as it should be by students, lecturers and units of institutions / educational units where the Internship held. Students prepare reports on the implementation of Internship 1 which is passed by the supervising lecturer and PKBM management. The score obtained by the student has been reported in the List of Participants and the Final Value (DPNA). Students can give and analyze the internship result and then make it into reflection result. Based on the reflection result can be known what and how the response or students'perception in the future to prepare themselves to beteachers as it has been formulated on the vision, mission and the objectives of the study program.

The extent to which students' reflection on Internship 1 can determine or influence their commitment in continuing their efforts to prepare themselves to become candidates of teacher and educational staff, in the study program needs to be scientifically studied through scientific research entitled "Perception About the Implementation Result Of Internship Program 1 And The Relationship With The Student Commitments Relating To Be A Prospective Educational Candidate".

\subsection{The Problems of Study} follow:

Based on the background of study above, the problem of study can be formulated as

a. How is the students' perception about the reflection of the internship program 1 in Non-Formal Education study program?

b. How is the students'commitment equip themselves to be a teacher in Non-Formal Education FIP Unimed?

c. Is there correlation between the results of reflection in the implementation of the Internship program 1 and the increase of students' commitment in equipping themselves as a candidate of teacher in Non-Formal Education FIP Unimed? 


\subsection{The Objectives of Study}

Based on the problem of study above, the objective of study are:

a. The students' perception about the reflection of the internship program 1 in NonFormal Education study program.

b. The students'commitment equip themselves to be a teacher in Non-Formal Education FIP Unimed.

There is correlation between the results of reflection in the implementation of the Internship program 1 and the increase of students' commitment in equipping themselves as a candidate of teacher in Non-Formal Education FIP Unimed.

\section{Methodology}

\subsection{Student Commitment}

Commitment is a term that is often be a topic of discussion both among scientists and laity. This commitment comes when a person or group of people agrees to do something that has been agreed upon before. The word commitment comes from English-commit, which means doing, commitment means making promises and responsibilities [1]. It means commitment can be seen as the basis of relationship and / or fostering relationships between individuals with each other, between individuals with groups, between groups of one with other groups.

In the world of learning, the term commitment is always a study in an effort to develop the learning activities can be achieved effectively and efficiently, so that the concept of student learning commitments or student learning commitments. Students who have a learning commitment are those who know, understand, be able to accept all the design of learning activities that have been set by colleges (universities, faculties, majors and courses) and determined to make it happen by doing these activities seriously and fully responsible.

Students as learners face directly with a number of tasks and obligations that have been formulated in such a way by the majors/courses on lecture tools such as curriculum, syllabus, lecture implementation plan (RPP), and other lectures, the principle of effective learning through the assistance of educators (lecturers) and professional staff in each field. This is in accordance with the opinion of [2] which states that commitment is the steadiness of the will, determination of attitude, and determination, to do better, to no longer repeat his wrongdoing or breaking it; will not do the same in the same place or elsewhere. This means commitment concerns the willingness, ability and determination of learners to do in accordance with the values or norms set by the group or organization.

Based on the opinion of some experts above can be said that the commitment of learning related to the attitude of the students promised to themselves and educational institutions to perform all rules and regulations that have been jointly established within the organization with good and full responsibility. As an attitude, learning commitment can be defined as a strong desire of learners to accept the values and or goals of the organization. [3] explains that organizational commitment can be defined as (1) a strong desire to remain as a member of a particular organization, (2) a desire to strive according to the will of the organization, and 3) certain beliefs and acceptance of organizational values and goals, it can be synthesized that 
students' learning commitments illustrate how students express their loyalty to the institution / study program through their attitude and / or behavior in carrying out their learning activities.

The characteristics of student learning commitment can be illustrated by analyzing Porter's opinion in [4] regarding organizational commitment characterized by three things: (1) acceptance of organizational values and objectives; (2) readiness and willingness to strive earnestly on behalf of the organization; (3) loyalty, that is the desire to remain as s member of the organization. Thus it can be said that the display of attitudes and learning behavior of LPTK students who have a commitment to learning are illustrated in (1) acceptance of norms and goals of study program, (2) readiness and willingness to carry out all duties and obligations of lectures seriously, (3) the determination to remain as a student in the study program to achieve the final goal, complete the study, ready to become a candidate of teacher at the institution of human resources empowerment that has been waiting in the community.

\subsection{Perception of the Internship Reflection}

Perception is one of the abilities that a person has to give meaning to something object or information. [4] defines perception as "the experience of objects, events, or relationships obtained by inferring information and interpreting messages".

Individual perception of some stimuli will take place in such a way based on certain principles or propositions. Some theories of perception, which Rachmat quotes from Krech and Crutchfield [4] formulate the first argument of perception: "Perceptions are selectively functional". This first premise explains that objects that are under pressure in our perceptions are usually objects that meet the goals of the individual who is perceptive.

Based on the description theory above can be said that the perception is a response or interpretation of a person against all that is felt or experienced and faced in his life. Thus, it can be mentioned also that student perception is response or interpretation of student to all that perceived or experienced in its lecture activity, such as perception on obligation to complete the six tasks, do extracurricular in the form of Student Creativity Program (PKM) by following the three stages of internship through the internship course and so on.

One course that needs to be perceived correctly by the students is the implementation of field practice courses or internships. Internships are generally interpreted as part of a system of on-the-job training held in an integrated manner between training in training institutions by working directly under the guidance and supervision of instructors or workers who are more experienced in the process of producing goods and services in the company, in order to master the skills or certain skills (Regulation of the Minister of Manpower and Transmigration No. Per. 22/Men/IX/2009 on Implementation of Internal Internship). This internship is usually done by students at the end of the completion of the lecture or vocational school (SMK) grade 3 as one of the main requirements to complete the education process (http://www.gajimu.com/main/tips-karir/sistem-magang-di -Indonesia). While job training is usually followed by a workforce who has signed a contract with a company or a particular institution in order to develop the competence and productivity of employees.

Internship at the top of the university level, especially at Medan State University (Unimed) has made fundamental changes in the application of the curriculum based on the Indonesian National Qualification Framework (KKNI), making it an internship for educational and non-educational programs. To education study program, the existence of internship course is intended for the internalization of teacher characters since the beginning of the teacher candidate decides the choice as a teacher, while for non-subject courses this course is expected to be a vehicle to introduce the world of work and profession for students according to their respective fields. 
The Non-Formal Education study program addresses this course by designing the implementation of internship courses in the scope of the activities by introducing various fields of Non-Formal education profession to the students. This internship program is a compulsory subject for FIP Unimed with three stages: (1) Internships 1, (2) Internships 2, and (3) Internships 3. Each stage has its own scope of achievement, because each stage of the internship also has different pre-graduation courses.

Internship program in Internships 1, 2, and 3 for students of Non-Formal Education study program aims to:

1. Extending student insight into the professional world of teachers/tutors by providing opportunities to experience directly the implementation of activities in PKBM.

2. Providing opportunities for students to establish networking with PKBM leaders, teachers/tutors in PKBM.

3. Giving experience to students to know firsthand management of PKBM, PKBM physical, studying citizen, socio-cultural of PKBM.

4. Applying theoretical knowledge into the world of practice so as to foster knowledge of work to fit the background of the field of student science.

5. Training the ability of students to be good individuals who are independent, able to behave, able to solve problems and make decisions in work.

6. Growing the ability to interact socially with others in the world of work.

The internship program designed in the Unimed curriculum can benefit many parties, especially students, who include:

1. Students can apply and improve the knowledge gained in the lecture bench.

2. Improving the ability of students in mastering the competence of the accountant profession gradually.

3. The opportunity to form self-confidence, because it can add and improve skills and professional skills.

4. Gaining understanding, appreciation and experience in the field of science.

5. Gaining experience through observation of the process of establishing accounting competence.

6. Gaining experience and appreciation through observation of the learning process in the classroom.

7. Gaining experience on how to think and work interdisciplinary, so that it can understand the existence of the relationship of science in overcoming the problems.

8. Acquire reasoning ability in conducting the review, formulation and solving profession problems in the field of knowledge that is involved in the business world.

The objectives and benefits of internships above, especially the Internship 1, will be achieved if the student can work with the directly related parties between the study program and the institution/unit of education where the Internship 1 is held. Various activities that must be done by students in Internships 1 so that students have a correct understanding, accurate about the world of work that they will be doing after completing the lectures in the choice program. The learning activities to be undertaken by the students at the Internship 1 have been designed in such a way by the university and study program, which includes observation (1) non-formal education management culture, (2) educator competence, and (3) learning process at the place of Internship 1 (PKBM).

In conducting the activities of Internships 1 above, educational institution, Unimed and study program have developed an instrument of observation that students can use during their stay at the internship. 


\subsection{Analytical/Theoritical Work}

The formation of a professional educator and educational staff is initiated from one's intention to become a professional educator and educational staff itself. This intention will be a strong motivation to endeavor to conduct any activities established by the self or outsiders directly related to the embodiment of what is intended. If a person has an intention become a teacher, then the intention will be the trigger to do everything related to the manifestation to be a teacher. The determination to do everything sincerely, earnestly and responsibly to realize what is intended] can be called as committed commitment or learning commitment for learners (students).

LPTK student's commitment to learn to make themselves as teachers or educational staff is encouraged or determined by many factors both from within themselves and from outside. If the factor from outside, that is the institution/ study program that is chosen in the form of the provision of various types and level of lecture activities as outlined in the curriculum, syllabus, RPP that must be done by the students, the perception factor from within the students will determine how to behave and implement all kinds and levels activities programmed by the study program.

Internship 1 is a type and an activity level or lecture program designed by LPTK institution (Non-Formal Education study program) to be implemented by the students. How students conduct Internship 1 will provide a variety of predictable learning experiences that will create an impression or self-perception on students about what, why, why, where LPTK graduates will later dedicate their life as educators or educational staff. Moreover, the Internship program 1 gives the students a chance to reflect on the activities during the follow up or perform the Internship 1. The results of reflection can be a determinant for students to think, analyze and resume commitment to continue his intention to finish his studies on the choice program.

Non-Formal Education students who have positive perception on the reflection result of Internship program 1 can be predicted to have high learning commitment, which is determined to prepare themselves to be educator and educational staff by accepting and implementing all lecture program activities that have been designed in such a way by the study program stages of the next lecture until it receives a pass mark (diploma) and is ready to serve in the community.Based on the above mindset can be synthesized that the perception about the reflection result of the implementation of the activities of Internships 1 has a positive relationship with the commitment of students prepare themselves as prospective education personnel based on the course of his choice.

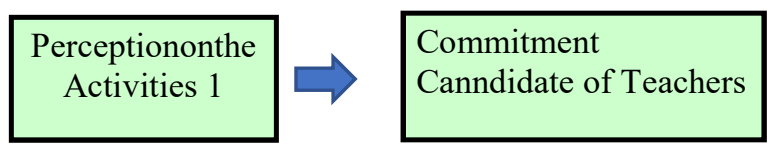

Fig. 1. There is a positive relationship between perceptions about reflection results on the activities of internship 1 with the students' commitment in preparing to be a candidate of teachers in Non-Formal Education study program FIP Unimed.

\subsection{Research Hypothesis}

Based on the theoretical framework and the above framework, the hypothesis proposed in this study is formulated as follows "There is a positive relationship between perceptions about reflection results on the activities of internship 1 with the students' commitment in preparing to be a candidate of teachers in Non-Formal Education study program FIP Unimed". 
The type of research used is descriptive quantitative research. It is designed to prove whether there is a significant relationship between perceptions about the reflection results on the activity of Internship 1 with the students' commitment in preparing themselves as a prospective teacher in Non-Formal Education study program with the design of the research work activities as follows.

This research was conducted four months from July to November 2017 in Non-Formal Education study program FIP Unimed for students from even semester academic year 2016/2017, with all students as population who have followed the Internship program 1 which amounted to 75 people with a sample of research as much as 75 people.

This research instrument used questionnaire in the form of Likert Scale. The data obtained in this study were analyzed descriptively by calculating the average price, standard deviation, variance, frequency distribution, mode and median and histogram of each variable. While Parametric statistics used are (a) Normality Test calculated by Liliefors formula, (b) Homogeneity Test, (c) Linearity Test and Simple Regression Meaning, (d) Correlation Coefficient Test by using Product Moment formula.

\section{Result and Discussion} below:

The results of data processing research for each variable can be summarized in Table 4.1

Table 1. Summary of Research Results Variable Description.

\begin{tabular}{cccc}
\hline \multirow{2}{*}{ No } & \multirow{2}{*}{ Descriptive Analysis } & \multicolumn{2}{c}{ Variable } \\
\cline { 3 - 4 } & & $\mathbf{X}_{\mathbf{1}}$ & $\mathbf{Y}$ \\
\hline 1 & Amount of Data (N) & 75 & 75 \\
2 & Maximum Score Ideal & 145 & 125 \\
3 & Ideal Minimal Score & 29 & 25 \\
4 & High Scores & 148 & 121 \\
5 & Lowest Score & 94 & 72 \\
6 & Mean (Average) & 112,95 & 104,73 \\
7 & Deviation Standard & 9,93 & 9,43 \\
8 & Modus & 112,08 & 105,64 \\
9 & Median & 112,12 & 105,02 \\
\hline
\end{tabular}

Based on Table 4.1 above can be seen the amount of data, highest score, lowest score, mean, deviation standard, mode and median of each research variable. In detail, the data of each variable can be described as follows:

\subsection{Perceptions on reflection results on the implementation of internship activities 1 (X1)}

Distribution of frequency and tendency of perception variable data about the reflection results on the implementation of internship program 1 (X1). Based on the data above can be seen that the perception variable data of the reflection results in organizing Internships program 1 (X1) tends to be enough, it means that students of internship 1 have a perception that is good, no less or less. 


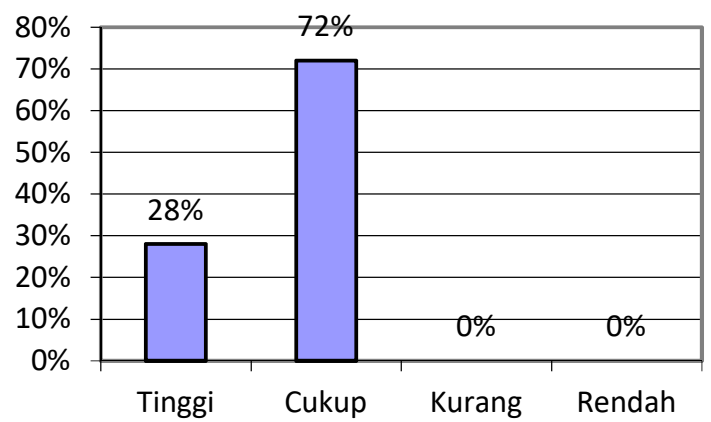

Fig. 2. Histogram data perceptions about reflection results on the activities of internship 1 a candidate of teachers in Non-Formal Education study program FIP Unimed (X1).

\subsection{Students' Commitment in Equipping Themselves to be a Candidate of Teacher in Non Formal Education Study Program FIP Unimed}

Distribution of frequency and tendency of variable data Students' Commitment in Equipping Themselves to be a Candidate of Teacher in Non-Formal Education Study Program FIP Unimed. Based on the data above, it can be seen that the variable data $(\mathrm{Y})$ of students' commitment in equipping themselves to be a candidate of teacher in Non-Formal Education Study Program FIP Unimed belongs to the high category, it means that the students have high commitment in equipping themselves to be prospective educators in Non-formal Education study program.

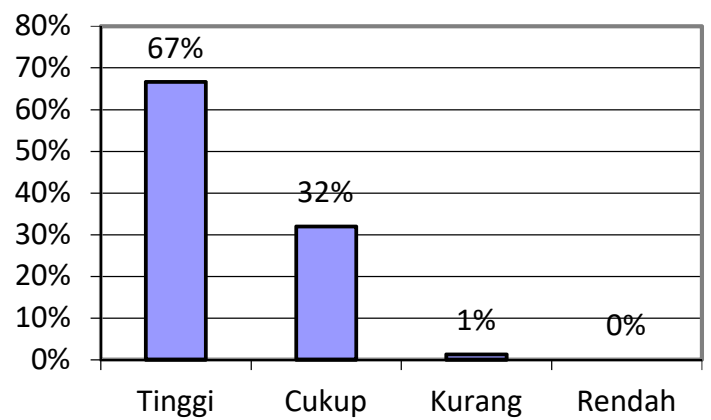

Fig. 3. Histogram data s about the students' commitment in preparing to be a candidate of teachers in Non-Formal Education study program FIP Unimed.

\subsection{Results of Requirements Analysis Test}

The requirements data analysis testing in this study is the normality test, linearity test and significance regression line. Homogeneity test is not necessary because the respondent does not do special treatment.

To obtain the normal data distribution from each research variable, normality testing is done by using Lilifors formula. The data for each research variable is called normal distribution, if the calculation result is smaller than Ltabel with $5 \%$ significance level. Summary of Result Normality test of each variable can be seen in Table 4.4 below. 
Table 2. Summary of Normality Test Results

\begin{tabular}{|c|c|c|}
\hline Research Variable & $\mathrm{L}_{\text {count }}$ & $\begin{array}{l}\text { Ltable } \\
(\alpha=0,05)(\mathrm{N}=45)\end{array}$ \\
\hline Variabel Y over X & 0,053 & 0,102 \\
\hline
\end{tabular}

Based on table above can be seen Lcount of all variables are smaller than Ltable (Lcount $<$ Ltable). It can be concluded that the distribution of variable data of students' commitment in equipping themselves to be a candidate of teacher in Non-Formal Education Study Program FIP Unimed(Y) on Perception about reflection result on Internship program 1 (X), normally distributed.

\subsection{Linearity and Simple Regression Test}

This test is used to find out whether or not linear relationship variable $\mathrm{X}$ to variable $\mathrm{Y}$ as a condition to use statistical techniques and regression analysis. Summary of significance test of regression coefficient and linearity for variables $\mathrm{Y}$ and $\mathrm{X}$ can be seen in Table 4.5 below.

Table 3. Overview of ANOVA Results Variable Y over X

\begin{tabular}{lccccc}
\hline \multicolumn{1}{c}{ Source } & Dk & JK & KT & Fhit & Ftab \\
\hline Variation & & & & & \\
Total & 75 & 829261 & & & \\
Coefficient a & 1 & 822680.33 & & & \\
Regression & 1 & 1614.89 & 1614.89 & & \\
(b/a) & & & & & \\
Rest & 73 & 4965.78 & 68.02438 & & \\
Suitable Tuna & 28 & 2082.74 & 74.38357 & 1.607143 & 7.19 \\
Error & 45 & 2082.74 & 46.28311 & & \\
\hline
\end{tabular}

Based on Table 4.5 above, it can be seen that Ftabel (dk: 1:75) is 7.19 while Fcount is 1.61. Apparently Fhitung $<$ Ftabel $(1.61>7.19)$ so it can be concluded that the regression equation $\mathrm{Y}=51,51+0,47 \mathrm{X}$ is linear at $\alpha=0,05$

\subsection{Results of Calculation Correlation Analysis among variables}

The results of calculation of correlation coefficient between variables of this study are stated in Table 4.5 and the results of the calculation of path coefficient in Table 4.6.

Table 4. Summary of the Correlation Coefficient Results (r)

\begin{tabular}{ccc}
\hline Relationship Variable & Correlation & $\mathrm{t} \mathrm{N}=73 ; \alpha=0,05$ \\
Xover Y & 0,496 & $4,87>0,166$ \\
\hline
\end{tabular}

Based on the data in Table 4.5. above can be seen that the price of the correlation coefficient between variables $\mathrm{X}$ with variabe $\mathrm{Y}$ reached 0.496 . After test of significance of correlation coefficient by using $\mathrm{t}$ test, obtained tcount equal to 4,87 , while price $\mathrm{t}$ level 0,05 equal to 0,166 , so tcount $>$ ttable $(4,87>0,166)$, it means the correlation coefficient between perception variable about result of reflection Organizing Internship Activities 1 (X) with students' commitment in equipping themselves to be a candidate of teacher in Non-Formal Education Study Program FIP Unimed(Y) is significant at 95 percent level. 


\subsection{Hypothesis Testing}

Based on the calculation of correlation coefficients mentioned above, the hypothesis proposed in the study stating that "" there is a relationship between Perceptions of Reflection Results in Organizing Internship program 1 with the students' commitment in equipping themselves to be a candidate of teacher in Non-Formal Education study program FIP Unimed "stated" received.

\subsection{Discussion of Research Results}

The students'commitment in equipping themselves to be a candidate of teacher in NonFormal Education study program FIP Unimed in this research is a variable that is determined by other variables called dependent variables. While the perception variable about the result of reflection on the implementation of the Internship program 1 is the independent variable that can determine the existence of the variable the students'commitment in equipping themselves to be a candidate of teacher in Non-Formal Education study program FIP Unimed.

The findings of this study explain that the perception of students on the results of the reflection of the implementation of internship program 1 tends to be quite (good). With the level or level of perception can have a significant relationship with the commitment of students continue their efforts to equip themselves to become prospective teacher in NonFormal Education study program later. This finding is enough to indicate that in order for students' commitment to make themselves as good educators in the future, the Internship 1 program and its advanced internships need to be designed and implemented in such a way effectively that it can lead to positive perception on students that the internship is a program that gives opportunity to them to experience (directly) the implementation of teacher profession performance (educational staff) so that they can grow their commitment to continue to pursue the profession in the program of study which has become the previous choice. Efforts that can be developed in improving student perceptions of the activities of apprenticeship is certainly not separated from the results of data analysis on each indicator of the perception itself.

\section{Conclusion}

Based on the results of the research data analysis can be drawn several conclusions research as follows:

a. Students' commitment in equipping themselves to be a candidate of teacher in NonFormal Education study program FIP Unimed tend to be high and sufficient with 98 percent achievement.

b. Perceptions on the reflection results on the implementation of internship program 1 in PKBM is quite high enough to reach 100 percent.

c. Perception of the reflection result on the implementation of internship program 1 has a significant positive correlation with the Students' commitmentin equipping themselves to be a candidate of teacher in Non-Formal Education study program FIP Unimed with a significant correlation coefficient of 0.496 at 95 percent level.

d. Contribution of Perception on reflection result on the implementation of Internship program 1 in PKBM on the Students' commitmentin equipping themselves to be a candidate of teacher in Non-Formal Education study program FIP Unimed reached 24.60 percent. 
Based on the conclusions of the above research, the following suggestions can be drawn as follow:

1. The Internship program in Unimed should be designed in such a way that it can form the best perception among students.

2. The service of Internship program held by Unimed with PKBM and other educational institution should be more professional so it makes the students aware about the important meaning of the internship

\section{References}

[1] J. M. Echols, Kamus Inggris Indonesia. Jakarta: Gramedia, 2003.

[2] Prayitno, Dasar Teori dan Praksis Pendidikan. Jakarta: Gramedia, 2009.

[3] F. Luthans, Perilaku Organisasi: Edisi Kesepuluh, Penerjemah Vivin Andhika Yuwono, dkk. 2006.

[4] Mowday, “Komitmen Karyawan Definisi dan Jenis,” J. Sumberd. Mns., 2009.

[5] J. Rachmat, Psikologi Komunikasi: Edisi Revisi. Bandung: Remaja Rosdakarya, 2005. 